DOI: $\underline{\text { https://doi.org/10.34069/AI/2021.42.06.22 }}$

How to Cite:

Bazhenova, A., Desyatnik, A., Mudretska, H., \& Pakipova, I. (2021). Ensuring the detection of property in the institute of property seizure. Amazonia Investiga, 10(42), 236-247. https://doi.org/10.34069/AI/2021.42.06.22

\title{
Ensuring the detection of property in the institute of property seizure
}

\section{Забезпечення виявлення майна в інституті накладення арешту на майно}

\author{
Received: June 10, $2021 \quad$ Accepted: July 13, 2021
}

Written by:

Anastasiia Bazhenova ${ }^{98}$

https://orcid.org/0000-0002-4652-0330

Anatolii Desyatnik ${ }^{99}$

https://orcid.org/0000-0002-2930-5102

Hanna Mudretska ${ }^{100}$

https://orcid.org/0000-0002-8203-1710

Inna Rakipova ${ }^{101}$

https://orcid.org/0000-0003-2456-0515

\begin{abstract}
The article is devoted to the study of certain issues of property detection in the institution of seizure of property. On the basis of comparative legal analysis, the possibility of ensuring the detection of property using search and seizure within the Criminal Procedure Code of the past and modern Criminal Procedure Code of Ukraine and foreign countries was assessed. The rights of the victim under the Convention for the Protection of Human Rights and Fundamental Freedoms are analyzed in terms of his/her right to a fair and public hearing within a reasonable time by an independent and impartial tribunal established by law to decide his/her civil rights and obligations. The application of the criminal procedural legislation of Ukraine is analyzed taking into account the practice of the European Court of Human Rights on the protection of human rights in relation to the rights of individuals or legal entities to peacefully own their property. Emphasis is placed on the fact that the previous provisions do not in any way restrict the right of the state to enact such laws as it deems necessary to exercise control over the use of property in accordance with the general interest. Scientific methods such as analysis,
\end{abstract}

Анотація

\footnotetext{
${ }^{98}$ Investigator of the Investigative Division of the Police Department № 1 of the Odessa District Police Department № 1 of the Main Directorate of the National Police in Odesa Oblast (Region), graduate student of the Criminal Procedure Department of the Odessa State University of Internal Affairs (Odessa, Ukraine).

${ }^{99}$ Head of the Monitoring Department of the Personnel Department of the Odessa State University of Internal Affairs, Police Colonel, Ph.D., (Odessa, Ukraine).

${ }^{100}$ Associate Professor of the Department of Criminal Procedure, Faculty of Training for Pre-trial Investigation, Odessa State University of Internal Affairs, Ph.D. (Odessa, Ukraine).

${ }^{101}$ Ph.D., Associate Professor of the Department of Criminal Procedure, Detective and Operational Investigation National University "Odessa Law Academy", Ukraine.
} 


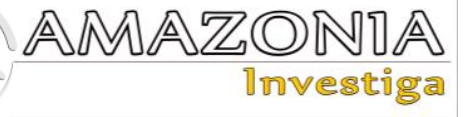

synthesis, formal-legal and comparative-legal method became the methodological basis of the research.

Keywords: investigator, prosecutor, search, seizure, temporary access to property and documents.

обмежують право держави вводити в дію такі закони, які вона вважає за необхідне, щоб здійснювати контроль за користуванням майном відповідно до загальних інтересів. Методологічною базою дослідження стали такі методи, як аналіз, синтез, формальноюридичний і порівняльно-правовий метод.

Ключові слова: слідчий, прокурор, обшук, виїмка, тимчасовий доступ до речей $\mathrm{i}$ документів.

\section{Introducción}

Ukraine, represented by state bodies, is implementing the strategic course of the state for full membership in the European Union, which corresponds to the provisions set out in Art. 85, 102,116 of the Constitution of Ukraine (Law No. 254K/96-VR, 1996).

In general, Ukraine is working consistently to bring national legislation in line with EU standards. One of the important steps was the adoption of the new Criminal Procedure Code of Ukraine (Law No. 4651-VI, 2012) nine years ago, which radically changed the rules of criminal proceedings. At present, many changes and additions have been made to the Criminal Procedure Code (Law No. 4651-VI, 2012), but a number of areas of procedural activity remain debatable and require further scientific development, consideration by the legislator and implementation in practice.

An important issue so far is to identify ways to identify and search for property that may be seized. This is due to the interests of the victim, which must be taken into account in the context of compliance with regulatory requirements for the implementation of the tasks of criminal proceedings, defined in Part 1 of Art. 2 of the Criminal Procedure Code of Ukraine (Law No. 4651-VI, 2012). Paragraph 2 of Part 1 of Art. 170 of the Criminal Procedure Code (Law No. 4651VI, 2012) stipulates that the investigator and the prosecutor must take the necessary measures to identify and search for property that may be seized in criminal proceedings. But the wording that "the investigator, the prosecutor must take the necessary measures" may not sufficiently provide compensation to the victim. In our opinion, it is necessary to provide law enforcement agencies with the opportunity to use a wider range of legal methods to identify and search for property, i.e. to expand the possibilities of identifying property that can be seized.

The purpose of the article is to analyze the problematic issues of property detection in the institution of seizure of property. The object of the study is the public relations that are formed during the detection of property in the institution of seizure of property. The subject of the study is Ukrainian and foreign regulations and the practice of their application, in particular, the European Court of Human Rights.

In addition, the authors of the study concluded that an effective way to identify and search for property that can be seized is a search, as well as, in certain circumstances, temporary access to things and documents, which in the future can be transformed into a seizure institution.

Based on the results of the study, amendments and additions to the Criminal Procedure Code of Ukraine (Law No. 4651-VI, 2012) are proposed. If the legislator will take them into account it will strengthen the possibility of identifying property that can be seized and further ensuring compensation by the prosecution through the institution of seizure of property.

\section{Theoretical Framework or Literature Review}

Certain problematic issues in the institution of seizure of property in criminal proceedings have been considered at different times by both scholars and practitioners. With the Criminal Procedure Code of Ukraine from 2012, problematic aspects of its application became apparent. Tatarov (2013) in the first year of the Criminal Procedure Code raised the issue of seizure of temporary confiscated property, and also drew attention to the need to provide in some cases the seizure of things and documents (seizures) that are relevant to criminal proceedings, by decision of the investigator, agreed with the prosecutor (Tatarov, 2013).

Smokov and Lisnichenko (2014) considered the problematic issues that arose in law enforcement 
activities related to the temporary seizure of property, as a result of which practical recommendations were given on how to act during the temporary seizure of property during inspection, search and detention and a personal search of the offender.

Rudenko (2015) touched upon the issue of disclosure of the concept and essence of seizure of property in criminal proceedings.

Kutskir (2015) investigated the grounds and procedural rules for restriction and deprivation of property rights on the basis of a reasoned court decision on the seizure of property.

Muzychenko (2016) described the procedure for the seizure of property, which is associated with the restriction of property rights during the pretrial investigation.

Lepei (2017) considered some issues concerning the clarification of the concept of seizure of property in criminal proceedings, disclosure of the essence of seizure of property, clarification of grounds, purpose, subject of seizure of property, as well as the status of persons subject to this measure to ensure criminal proceedings. decision on seizure of property and its cancellation, clarification of the place and significance of seizure of property in the system of procedural decisions in criminal proceedings.

In studying the legal mechanism for ensuring the inviolability of property rights in criminal proceedings, Drozd (2019) described the seizure of property as a way to limit and deprive property rights in criminal proceedings.

Verkhoglyad-Herasymenko (2017) considered the norms of the Criminal Procedure Code of Ukraine, which determine the purpose, grounds and conditions of seizure of property of third parties in criminal proceedings.

Hlovyuk (2017) considered several problematic issues related to the seizure of property, such as the seizure of property in criminal proceedings, including to ensure the preservation of material evidence. Also, Hlovyuk (2016) studied the problems of regulations and the practice of evidence in resolving the issue of seizure of property in the context of the prosecution as a subject of evidence.

These and other scholars have made a huge contribution to the interpretation and clarification of the new legislation related to the seizure of property, assessed the effectiveness of the application of this legislation and proposed changes to it. At the same time, the issues of property detection in the application of the institution of seizure of property, which further provides compensation for damages by the prosecution through the institution of seizure of property, including compensation to the victim, remain incompletely studied.

The article aims to study certain issues of property detection in the application of the institution of seizure of property, and one way to identify and search for property that can be seized is a search, as well as in certain circumstances the temporary access to things and documents. The latter in the future can be transformed into the institution of special seizure.

\section{Methodology}

The fundamental method of any scientific research is the method of analysis. It allows to know all the manifestations of the studied phenomenon and draw the necessary conclusions about its condition and further development. This article is not an exception to the general rule, as its authors used this method as the main one in the study of the detection and seizure of property of the accused by state officials in criminal proceedings for crimes. In particular, the method of analysis allowed to study the current criminal procedure legislation of Ukraine for compliance with the best models of European legislation and to draw sound conclusions about the directions of its improvement.

Another general scientific method used by the authors of the article during their research was the method of synthesis. It is this method that made it possible to capture and summarize the problematic issues related to the detection and seizure of the accused's property, which became the basis for formulating the proposals of the authors of this article to amend the current criminal procedure legislation of Ukraine.

With regard to formal-legal and comparativelegal methods, they can be attributed to special scientific methods. They are, among others, the basic methods in carrying out any serious scientific legal research. In this article, these methods allowed at a high professional level to analyze and compare domestic and foreign legislation governing the detection and seizure of property of a person accused of a crime. These methods also allowed the authors to make sound proposals for improving domestic legislation in the study area. 


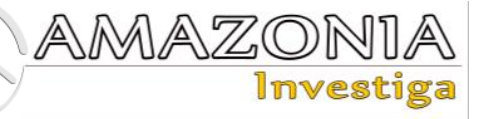

The authors also used special research methods: comparative legal method - to investigate national and international legislation, current criminal procedure law relating to the institution of seizure of property, search, temporary access to property and documents, seizures; special legal method: logical-legal and systematic methods were used for the formulation of relevant conclusions.

\section{Results and Discussion}

Assessing the state of regulation by criminal procedural law of the possibility of ensuring the rights of the victim through the institution of search and seizure, it should be noted that the Criminal Procedure Code of Ukraine of 1960 (Law No. 1001-05, 1960), provided more opportunities for the accused party to use search and seizure to establish, seize the valuables and property of the accused or suspect in order to secure a civil lawsuit. Unfortunately, the current Criminal Procedure Code does not provide for the purpose of conducting a search, temporary access to property and documents, as securing a civil lawsuit.

Given the above, in our opinion, the issue of protection of the victim from the consequences of a criminal offense in terms of compensation for damage, including the proper provision of a civil lawsuit, is given insufficient attention by the legislator. In connection with the above, it is appropriate to indicate that the victim has the right in accordance with paragraph 1. Art. 6 "Right to a fair trial" of the Convention for the Protection of Human Rights and Fundamental Freedoms (United Nations, 1950), according to which everyone has the right to a fair and public hearing within a reasonable time by an independent and impartial tribunal established by law to decide his rights and obligations of civil nature.

In accordance with Part 5 of Art. 9 of the Criminal Procedure Code of Ukraine (Law No. 4651-VI, 2012), the criminal procedure legislation of Ukraine is applied taking into account the case law of the European Court of Human Rights. The judgment of the European Court of Human Rights in Zhushman v. Ukraine No. 13223/05 of 28 May 2009 states that "every natural or legal person is entitled to the peaceful enjoyment of his possessions. No one shall be deprived of his possessions". This decision is based on the provisions of Art. 1 "Protection of property" of Protocol No. 1 to the Convention for the Protection of Human Rights and Fundamental Freedoms (United Nations, 1952), which provides that every natural or legal person is entitled to the peaceful enjoyment of his possessions. No one shall be deprived of his possessions except in the public interest and subject to the conditions provided for by law and by the general principles of international law. However, the preceding provisions do not in any way restrict the right of a State to enact such laws as it deems necessary to control the use of property in the general interest or to ensure the payment of taxes or other charges or fines.

In other words, property rights are not absolute and should not dominate state interests. The state itself, represented by the authorized bodies, has the right to establish and enforce such laws as it deems necessary to exercise control over the use of property in accordance with the general interest. Accordingly, ensuring a prompt, complete and impartial investigation and trial so that everyone who has committed a criminal offense is brought to justice, as defined in Part 1 of Art. 2 of the Criminal Procedure Code of Ukraine, is a general interest specified in the Protocol (№ 1) of the Convention for the Protection of Human Rights and Fundamental Freedoms of 1952.

In accordance with Part 1 of Art. 170 of the Criminal Procedure Code of Ukraine (Law No. 4651-VI, 2012), the investigator, prosecutor must take the necessary measures to identify and search for property that may be seized in criminal proceedings, in particular by requesting the necessary information from the National Agency of Ukraine for detection, search and management of assets obtained from corruption and other crimes, other state and local government bodies, individuals and legal entities.

The position of this article that the investigator discovers the property in particular by requesting the necessary information from the National Agency of Ukraine for Detection, Investigation and Management of Assets Obtained from Corruption and Other Crimes, other state and local governments, individuals and legal entities, is not fully meets the needs of practice and in our opinion should be expanded in order to allow law enforcement agencies to use a greater set of legal means of detecting such property, i.e. to expand the possibilities of detecting property.

The question arises, how to identify and search for property?

Thus, in our opinion, one of the ways to identify and search for property that can be seized is a search, as well as in certain circumstances and 
temporary access to property and documents. The latter in the future can be transformed into the institution of special seizure. This is explained by the fact that the investigator, the prosecutor, may legally enter the dwelling or other property of a person or part of during a search and temporary access to things and documents.

Accordingly, during the search, temporary access to things and documents, the investigator, the prosecutor may directly identify the property listed in Art. 170 of the Criminal Procedure Code, namely in respect of which there is a set of grounds or reasonable suspicions that it is evidence of a criminal offense, is subject to special confiscation from the suspect, accused, convicted, third parties, confiscation from a legal entity to secure a civil claim, recovery from a legal entity illegal gain, possible confiscation of property.

However, according to Part 1 of Art. 234 of the Criminal Procedure Code (Law No. 4651-VI, 2012), the search is conducted only for the purpose of:

- detection and recording of information about the circumstances of a criminal offense;

- finding the instrument of a criminal offense;

- finding property that was obtained as a result of its commission;

- $\quad$ establishing the location of wanted persons.

In this case, the search for a tool of a criminal offense - is the search for property in respect of which there is a set of grounds or reasonable suspicion that it is evidence of a criminal offense, according to Part 1 of Art. 170 of the Criminal Procedure Code (Law No. 4651-VI, 2012), the said property may be seized under Part 1 of Art. 170 of the Criminal Procedure Code (Law No. 4651-VI, 2012).

Finding only the property that was obtained as a result of its commission does not cover the entire set of property that can be seized in criminal proceedings under Part 1 of Art. 170 of the Criminal Procedure Code (Law No. 4651-VI, 2012).

The legislator ignored the property listed in Part 1 of Art. 170 of the Criminal Procedure Code (Law No. 4651-VI, 2012), which may be seized, namely property in respect of which there is a set of grounds or reasonable suspicions to believe that it: is subject to special confiscation from the suspect, accused, convicted, third parties; subject to confiscation from a legal entity, subject to securing a civil lawsuit; is subject to ensuring recovery from the legal entity of the received illegal benefit; subject to ensuring the possible confiscation of property.

Summarizing the above, it can be noted that the main purpose of the search is not to identify property that may be seized. At the same time, the law obliges, namely Part 1 of Art. 170 of the Criminal Procedure Code (Law No. 4651-VI, 2012), that the investigator, the prosecutor must take the necessary measures to identify and search for property that may be seized in criminal proceedings. It is obvious that the Criminal Procedure Code (Law No. 4651-VI, 2012) has certain omissions in this part, which do not allow the prosecution to fulfill the specified regulatory requirements of Par. 2 Part 1 of Art. 170 of the Criminal Procedure Code (Law No. 4651-VI, 2012), as well as to comply with the regulatory requirements of Part 1 of Art. 2 of the Criminal Procedure Code on the tasks of criminal proceedings in terms of protection of the individual (including the victim), society and the state from criminal offenses, protection of rights, freedoms and legitimate interests of participants in criminal proceedings (including the victim), as well as ensuring prompt, complete and impartial investigation and trial so that anyone who commits a criminal offense is prosecuted to the extent of their guilt.

To solve this problem, it is necessary to refer to the developments of the legislation of previous years, modern legislation of other countries, the practice of law enforcement of this legislation.

For example, the wording of the provisions concerning the seizure of property in Art. 174 of the Criminal Procedure Code (Law No. 4651-VI, 2012) of the former Georgian SSR, approved on December 30, 1960, which is called "Seizure of property". It stated the following: "In order to secure a civil lawsuit or possible confiscation of property, the investigator must seize the property of the accused, suspect or persons legally liable for their actions, or other persons from whom the property acquired is located by criminal means (Part 1). Seizure of property can be carried out simultaneously with the seizure or search or independently" (Part 2) (Yskandyrov, 2010).

For comparison, it is necessary to point out the possibility of conducting a search under the Criminal Procedure Code of Ukraine adopted in 1960. Thus, in accordance with the Law of Ukraine of June 21, 2001, Law No. 2533 "On Amendments to the Criminal Procedure Code of Ukraine", Art. 177 of the Criminal Procedure 


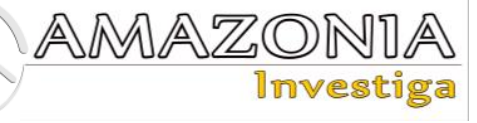

Code is set out in a new wording and was entitled "Grounds for the search and the procedure for consent to its conduct."

According to the new wording, a search is carried out in cases where there are sufficient grounds to believe that the instruments of the crime, things and valuables obtained by criminal means, as well as other items and documents relevant to establishing the truth in the case or securing a civil claim are in a certain room or place or in any person. A search is also carried out when there is sufficient evidence that there are wanted persons, as well as corpses or animals in a certain room or place.

The possibility of conducting a search in cases where there are sufficient grounds to believe that objects and documents relevant to securing a civil claim are located in a certain room or place or in any person under Article 177 of the Criminal Procedure Code of Ukraine in 1960 has existed since 2001 till the entry into force of the Criminal Procedure Code in 2012, but was not enshrined in the Criminal Procedure Code in 2012, which negatively affects the level of further securing of a civil claim and compensation for damages.

The authors of the textbook "Criminalistics" referring to Part 3 of Art. 177 of the Criminal Procedure Code of Ukraine in 1960, on the eve of the new Criminal Procedure Code in 2012, stated that in urgent, extreme cases, a search may be conducted by order of the investigator, but with mandatory notification of the prosecutoer within 24 hours of the search and its results. The authors note that the search is often accompanied by such a degree of procedural coercion as the seizure of property, which is expressed in the prohibition of the person in whom the property is described to dispose of it (Blahuta, Sybirna, \& Baraniak 2012).

That is, in fact, the search was allowed to ensure a civil lawsuit in a direct statement, in contrast to the current version of Part 1 of Art. 234 of the Criminal Procedure Code of 2012. Unfortunately, the established legislative practice of using a search to secure a civil lawsuit was not taken into account by the legislator when adopting the Criminal Procedure Code in 2012, as well as during the 9 years of its further existence.

The fact that the previous legislation allowed the seizure of property at the same time as the search and seizure needs to be noted. It is interesting that according to Part 2 of Art. 175 of the Criminal
Procedure Code of the Russian RSFR (Law No. 3275, 1960), Part 3 of Art. 174 of the Criminal Procedure Code of the Byelorussian SSR (Law No. 29.12.1961, 1961), Part 2 of Art. 174 of the Criminal Procedure Code of the Georgian SSR (Central Committee of the Communist Party of Georgia, 1961), Art. 195 of the Criminal Procedure Code of the Lithuanian SSR (1972), Art. 175 of the Criminal Procedure Code of the Latvian SSR (1961) seizure of property may be carried out simultaneously with the seizure or search or independently. Thus, the authors of the textbook "Soviet Criminal Procedure" noted in the criminal process of the Russian RSFR that the seizure of property as an investigative action is carried out, as a rule, simultaneously with the seizure and search (Bozhiev, (1990). Such powers gave the investigator urgent and effective procedural opportunities in the use of search and seizure at the institution of seizure of property in order to carry out the tasks of criminal proceedings.

It is noteworthy that despite some uniformity of criminal procedure legislation of the former Soviet republics, some Criminal Procedure Codes at the time had their own peculiarities, including the possibility of confiscating property during a search, seizure to secure a civil lawsuit or confiscation of property.

For example Art. 137 of the Criminal Procedure Code of the Kazakh SSR (1969), Art. 196 of the Criminal Procedure Code of the Azerbaijan SSR (1971) provided that during the seizure and search only items and documents that are relevant to the case may be seized, as well as valuables or property in order to secure a civil lawsuit or confiscation of property. Art. 162 of the Criminal Procedure Code of the Armenian SSR (1971) provided that during a search or seizure may be seized items and valuables obtained by criminal means, items and documents relevant to the criminal case, as well as the values and property of the accused to secure a civil lawsuit or confiscation of property.

Art. 174 of the Criminal Procedure Code of Georgian SSR provided that, if necessary, the seized property could be confiscated. When seizing money deposits, any transactions on them are stopped (Central Committee of the Communist Party of Georgia, 1961).

The authors of the textbook "Criminology" edited by Belkin (2001) noted that the search tasks under Art. 168 of the Criminal Procedure Code of the RSFSR was to reveal property that could be confiscated or serve to secure a civil 
lawsuit. The investigator was obliged to seize the property of the accused, suspect or a person legally liable for his actions, as well as other persons who have property acquired by criminal means.

The authors of the textbook "Investigative actions (procedural characteristics, tactical and psychological features)" (Ministry of Internal Affairs of the USSR, 1984) within the Criminal Procedure Code of the Russian Federation indicated the possibility of seizing property simultaneously with the search and seizure or independently. It was noted that in order to seize the property, the investigator makes a reasoned decision.

Part 1 of Art. 186 of the Criminal Procedure Code of Ukraine of 1960 "Seizure of objects and documents" provided that during a search or seizure may be seized valuables and property of the accused or suspect in order to secure a civil lawsuit or possible confiscation of property.

We consider it necessary to emphasize that in the Criminal Procedure Code of Ukraine of 1960 the procedure for search and seizure was regulated in Chapter 16 "Search and seizure". In our opinion, this is not accidental and is explained by similar tasks that are solved both during the search and during the seizure. Thus, in accordance with Part 1 of Art. 177 of the said Criminal Procedure Code "Grounds for conducting a search and the procedure for granting consent to conduct it", the search was conducted in cases where there are sufficient grounds to believe that the instrument of the crime, things and valuables obtained by criminal means, as well as other items and documents values for establishing the truth in the case or securing a civil lawsuit, are in a certain room or place or in any person.

The seizure had similar tasks. In accordance with Art. 178 of the Criminal Procedure Code of Ukraine of 1960 "Grounds for seizure and the procedure for consent to seizure", seizure was carried out in cases when there was accurate evidence that items or documents relevant to the case are in a certain person or place.

The difference between a search and a seizure is the degree of awareness of the location of objects or documents. That is, when searching for information about things and valuables, other items and documents are less specific and require search activities.

At the same time, the legislator, in our opinion, unjustifiably in the Criminal Procedure Code of
Ukraine in 2012 sections between search and related to the search temporary access to things and documents, this institution of temporary access is actually created based on the last seizure under the 1960 Criminal Procedure Code. Thus, according to the Criminal Procedure Code in 2012, the institution of temporary access to things and documents is classified as a measure of criminal proceedings, which are listed in Chapter II of the Criminal Procedure Code of Ukraine. Although, in essence, this institution is aimed at obtaining evidence through investigative (search) actions and should be placed next to the search, part of the regulation of the search and temporary access to things and documents should be placed in joint articles. It should be added, that, in general, we take the position that the institution of temporary access to things and documents should be transformed into a time-tested institution of seizure. These institutes of search and seizure in the framework of our study are of interest to us as tools for identifying property that can be seized.

An essential feature of this legislation was that the investigator had some independence in deciding to seize property, including at the same time as seizure or search. In some countries of the European Union, the prosecution also has the right to seize property immediately if necessary, but with further notification to the court to further verify the validity and legality of the measures taken. Peculiarities of procedural regulation of the institution of seizure of property in other countries should be used in national legislation to improve the mobility of the institution, reduce the chain of the decision to seize property from the moment of need to conduct proper registration of results.

To reject possible allegations that the provisions of the Criminal Procedure Code of 1960 are quite outdated, including in terms of searches, seizures, and other investigative actions, it is necessary to refer to the current versions of the Criminal Procedure Code of the European Union and other countries, that are listed as countries with a developed legal culture and to which there are no significant complaints about their criminal procedure legislation. The Criminal Procedure Code of these states, as well as the Criminal Procedure Code of Ukraine in 1960, the Criminal Procedure Code of the republics of the former USSR, do not have a complicated search procedure and allow them to be conducted in a short time from the need to conduct such a search until its completion, registration of results and notification to the court or to the prosecutor's 


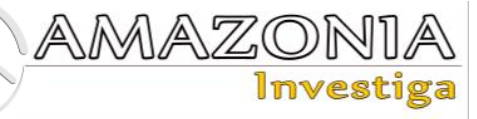

office about the fact of its carrying out, for check of legality of its carrying out.

In our opinion, the approach of the legislators of the Republic of Estonia to the search, including its purpose, is indicative. Thus, in paragraph 1 of Art. 91 "Search" of the Criminal Procedure Code of the Republic of Estonia (2003) stipulates that the purpose of the search is to find in the building, premises, vehicle or in a fenced area of the object, which is used as evidence or confiscated; a document, subject or person necessary for the consideration of a criminal case; property subject to seizure for confiscation or compensation for the damage caused by the crime, or a corpse, or detention of the wanted person. That is, in contrast to the Criminal Procedure Code of Ukraine, the purpose of a search of the Estonian Criminal Procedure Code is to identify property that is subject to seizure to confiscate or compensate for the damage caused by the crime.

Paragraph 2 of this article stipulates that, unless otherwise provided by this Code, a search may be conducted at the request of the prosecutor's office based on a decision of a preliminary investigation judge or a court decision.

Noteworthy is that according to paragraph 3 of Art. 91 of the Criminal Procedure Code of the Republic of Estonia (2003), a search may be carried out based on a prosecutor's order, except for a search at a notary or law firm, or a search of a person processing information for journalistic purposes, if there are grounds to believe that the suspect uses or used at the time of the crime or during the pre-trial proceedings, and the person is suspected of committing a crime referred to in part 2 of Article 126-2 of this Code.

That is, the search is carried out without a complicated procedure of prior agreement with the investigating judge, as provided for in Articles 234-235 of the Criminal Procedure Code of Ukraine. It is of interest to search under the Criminal Procedure Code of the Republic of Estonia, including the possibility of detecting during the search of property to be seized for the purpose of confiscation or compensation for damage caused by the crime.

Article 126-2 of the Criminal Procedure Code of the Republic of Estonia has a reference character and lists a number of articles of the Criminal Code of the Republic of Estonia. The specified list includes, for example, Art. 101 "Intentional homicide under aggravating circumstances", Art. 102 "Murder of the mother of her newborn child", Art. 108 "Intentional infliction of grievous bodily harm", Art. 110 "Infliction of particularly grievous bodily harm in excess of the limits of necessary defense", Art. 141 "Robbery", Art. 141-1 "Theft by misappropriation, embezzlement or abuse of office" of the Criminal Code of the Republic of Estonia (2003).

The efforts of the legislators of the Republic of Estonia to reduce the procedure for approving a search in the event of an urgent need for it are worthy of positive assessment. So, in item 5 of Art. 91 "Search" of the Criminal Procedure Code of the Republic of Estonia stipulates that in urgent cases, when timely execution of the search warrant is not possible, under the conditions specified in part 3 of this article, the search may be carried out with the permission of the prosecutor's office. Paragraph 6 of this article stipulates that when conducting a search on the grounds specified in parts 3 and 5 of this article, the judge of the preliminary investigation shall be notified through the prosecutor's office during the first working day following the search. The judge of the preliminary investigation shall make a decision on declaring the search admissible by his decision, which may be made in the form of an accompanying inscription on the decision of the prosecutor's office. Part 7 of this article provides that in the case referred to in part 5 of this article (when applying a search to the person being searched, or an adult member of his family or a representative of a legal entity, state or municipal institution where the search is conducted) explained the circumstances referred to in paragraph 4 of this article and the reasons why the search is carried out on urgent grounds. The person shall sign the resolution to clarify the circumstances. In the absence of an appropriate person or representative, it is necessary to involve a representative of the local government. Part 10 of Art. 91 of the Criminal Procedure Code of the Republic of Estonia stipulates that during a search, all objects that are subject to confiscation or are obviously evidence in criminal proceedings may be seized if they were found without searching in a clearly visible place or during a reasonable search made to find the objects sought.

Thus, the Republic of Estonia, which is a part of the European Union and whose legislation complies with the norms of the European Union, has more effective search mechanisms without a court decision, which takes some time to prepare and adopt, to identify property that is subject to seizure for confiscation or compensation for damage caused by the crime. 
Given the above, it is proposed Part 1 of Art. 234 of the Criminal Procedure Code to read as follows:

«Article 234. Search

1. A search shall be carried out for: identifying and recording information on the circumstances of the commission of a criminal offense; finding the instrument of a criminal offense; establishing the location of wanted persons; finding a property that may be seized following Art. 170-175 of the Criminal Procedure Code.

2. A search shall also be carried out when there is sufficient evidence that wanted persons, corpses, or animals are present in a particular room or place.

3. During the search, only items and documents relevant to the proceedings may be seized, as well as property to secure a civil lawsuit, recover from the legal entity the obtained illegal benefit, possible fine and possible confiscation of property, subject to special confiscation from the suspect, accused, convicted, third parties, confiscation from a legal entity».

It should be noted that following Part 1 of Art. 159 of the Criminal Procedure Code of Ukraine "General provisions of temporary access to things and documents", temporary access to things and documents is to provide the party to the criminal proceedings with a person in possession of such things and documents, the opportunity to read them, make copies and withdraw them their excavation). It must be acknowledged, that the current concept of temporary access to things and documents does not fully allow the use of this institution to identify property that may be seized, to determine the financial condition of the suspect, the accused.

The way out of this situation is to change the concept of temporary access to things and documents and move to the classic seizure. To confirm this, it should be noted that in general, as of 2021, i.e. after 9 years since the Criminal Procedure Code of 2012, the problem of slow temporary access to things and documents has not been resolved. Thus, back in 2013, Tatarov pointed out that the content of Art. 163 of the Criminal Procedure Code of Ukraine, the investigating judge, after receiving a request for temporary access to documents, summons the person in possession of such documents (Part 1) and then considers such a request with the participation of this person (Part 4). (2) Thus, in fact, for example, to obtain a decision of the investigating judge on temporary access to information on open bank accounts, cash flows, credit files stored in banking institutions, it is necessary to wait for a representative of the banking institution to appear in court. At the same time, the appearance before the pre-trial investigation body and the court of such a representative of an institution that does not have a representative office in the region where the investigation is carried out seems doubtful (in no way guaranteed). Such a procedure wastes time, which is quite significant at the initial stage of the investigation when it is necessary to remove and provide a proper assessment of documents that directly or indirectly contain information indicating a criminal offense. Meanwhile, Part 2 of Art. 163 of the Criminal Procedure Code of Ukraine of Ukraine provides for the procedure for the investigating judge to request temporary access to things and documents, according to which the summons of the person in whose possession they are, is not mandatory, namely if the investigator proves sufficient grounds to believe that there is a real threat of change or destruction of things or documents. However, it is not always possible to prove the existence of such a threat. In particular, this applies to proceedings that have just begun and have not yet been sufficiently investigated and covert investigative actions, the results of which could prove to the investigating judge that a person who is not a suspect and in possession of documents relevant to the investigation, may knowingly replace or destroy them to avoid liability (or assist others). No less problematic is the situation when a person who owns things or documents reports the impossibility of enforcing a court decision on temporary access to them, citing, including unreasonably, their absence. In this case, additional time is required to resolve the issue of searching (under Article 234 of the Criminal Procedure Code of Ukraine) to identify the necessary things or documents. The request to conduct a search to find them requires approval. Forced "stretching" during such a procedure does not exclude the possibility of destruction or substitution of essential things for the investigation and documents to the person who owns them. An option to resolve this issue is to simplify the legislative regulation of this procedure. It would be possible to provide in some cases for the seizure of things and documents (seizures) that are relevant to criminal proceedings, by decision of the investigator, agreed with the prosecutor. This would significantly reduce the time spent on obtaining evidence, will facilitate a rapid and complete investigation in ensuring compliance with the 


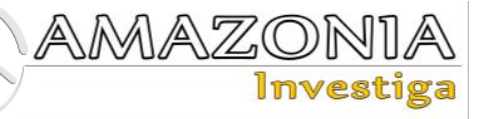

rights of citizens by approving such a decision of the investigator to the prosecutor.

Tatarov's proposal to provide in the legislation for the possibility of seizing items and documents (seizures) relevant to criminal proceedings in certain cases, according to the decision of the investigator, agreed with the prosecutor, is appropriate and needs further development.

According to the results of the study, the proposed changes and additions to the Criminal Procedure Code of Ukraine, taking into account which the legislator will strengthen the possibility of securing damages by the prosecution through the institution of seizure of property, will provide additional procedural opportunities to the victim and civil plaintiff.

\section{Conclusions}

Part 1 of Art. 234 of the Criminal Procedure Code to read as follows:

«Article 234. Search

1. A search shall be carried out for: identifying and recording information on the circumstances of the commission of a criminal offense; finding the instrument of a criminal offense; establishing the location of wanted persons; finding a property that may be seized following Art. 170-175 of the Criminal Procedure Code.

2. During the search, only items and documents relevant to the proceedings, as well as valuables or property may be seized to secure a civil lawsuit, recover from the legal entity the illegal benefit, possible fine, and possible confiscation of property, subject to special confiscation from the suspect, accused, convicted person, third parties, confiscation from a legal entity.

3. A search is also carried out when there is sufficient evidence that there are wanted persons, and corpses or animals in a special room or place».

4. It must be acknowledged, that the current concept of temporary access to things and documents does not fully allow the use of this institution to identify property that may be seized, to clarify the financial condition of the suspect, accused. The way out of this situation is to change the concept of temporary access to things and documents and move to the classic seizure. It is necessary to provide in the legislation the possibility to carry out in some cases the seizure of things and documents (seizures) that are relevant to criminal proceedings, by decision of the investigator, agreed with the prosecutor. This would significantly reduce the time spent on obtaining evidence, will facilitate a rapid and complete investigation in ensuring compliance with the rights of citizens by approving such a decision of the investigator to the prosecutor.

\section{Bibliographic references}

Azerbaijan Soviet Socialist Republic (1971). Code of Criminal Procedure of the Azerbaijan Soviet Socialist Republic. Baku: Azerbaijan state publishing house. Recovered from https://books.google.com.ua/books/about/\%D $0 \% \mathrm{~A} 3 \% \mathrm{D} 0 \% \mathrm{~B} 3 \% \mathrm{D} 0 \% \mathrm{BE} \% \mathrm{D} 0 \% \mathrm{BB} \% \mathrm{D} 0 \% \mathrm{~B}$ E\%D0\%B2\%D0\%BD\%D0\%BE_\%D0\%BF\% D1\%80\%D0\%BE\%D1\%86\%D0\%B5\%D1\%8 1\%D1\%81\%D1\%83\%D0\%B0\%D0\%BB\%D 1\%8C.html?id=XRxhzQEACAAJ\&redir_esc $=\mathrm{y}$

Belkin, R.S. (2001). Forensics. Moscow: NORMA.

Blahuta, R.I., Sybirna, R.I., \& Baraniak V.M. (2012). Kryminalistyka. Kyiv: Atika.

Bozhiev, V.P. (Ed.). (1990). Soviet criminal process. Moscow: Juridical Literature.

Central Committee of the Communist Party of Georgia. (1961). Criminal Procedure Code of the Georgian SSR. Tbilisi: publishing house of the Central Committee of the Communist Party of Georgia. Recovered from http://lawlibrary.ru/izdanie3005.html

Code of Criminal Procedure of the Armenian Soviet Socialist Republic. (1971). Erevan: Aiastan. Recovered from https://www.legislationline.org/download/id/4 261/file/Armenia_CPC_am2006_ru.pdf Code of Criminal Procedure of the Latvian Soviet Socialist Republic. (1961). Riga: Latvian state publishing house.

Code of Criminal Procedure of the Republic of Estonia. (2003). Recovered from https://www.legislationline.org/download/id/6 462/file/Estonia_CC_as_of_2002_ru.pdf Criminal Procedure Code of the Kazakh SSR. (1969). Alma-Ata: Publishing house "Kazakhstan". Recovered from https://adilet.zan.kz/rus/docs/K590001000_

Drozd, A.V. (2019). Ensuring the inviolability of property rights in criminal proceedings: author's (ref. dis. ... cand. jurid. Science). Kharkiv National University of Internal Affairs, Kharkiv, 24 p. Recovered from http://dspace.univd.edu.ua/xmlui/bitstream/ha ndle/123456789/5881/aref_Drozd\%20A\%20 V_2019.pdf?sequence $=1 \&$ isAllowed $=y$ 
European Court of Human Rights. (2009). Judgment No. 13223/05 of June 28, 2009, in the case of Zhushman v. Ukraine. Recovered from

http://hudoc.echr.coe.int/app/conversion/docx $/$ ?library=ECHR\&id $=001-$

92774\&filename $=$ CASE $\% 200 F \% 20 Z H U S H$

MAN\%20v.\%20UKRAINE.docx\&logEvent= False

Hlovyuk, I.V. (2016). The prosecution as a subject of evidence in deciding on the seizure of property. Visnyk kryminalnoho sudochynstva, 3, 18-25. Recovered from http://nbuv.gov.ua/UJRN/vkc_2016_3_4

Hlovyuk, I.V. (2017). Some issues of seizure of property in order to preserve material evidence. Odessa: Informatsiine zabezpechennia rozsliduvannia zlochyniv. Recovered from http://dspace.onua.edu.ua/handle/11300/9402. Kutskir, H.M. (2015). The principle of inviolability of property rights: the concept, content and implementation in criminal proceedings. Odessa: Phoenix. Recovered from

https://core.ac.uk/download/pdf/50594997.pd $\mathrm{f}$

Law No. 2533, On Amendments to the Criminal Procedure Code of Ukraine. Bulletin of the Verkhovna Rada of Ukraine, Kyiv, Ukraine, June 21, 1996. Recovered from https://zakon.rada.gov.ua/laws/show/253314 ?find $=1 \&$ text $=177 \#$ w $1 \_3$

Law No. 254к/96-VR, Constitution of Ukraine. Bulletin of the Verkhovna Rada of Ukraine, Kyiv, Ukraine, June 28, 1996. Recovered from https://zakon.rada.gov.ua/laws/show/254\%D0 \%BA/96-\%D0\%B2\%D1\%80\#Text

Law No. 29.12.1961, the Criminal Procedure Code of the Byelorussian SSR. Byelorussian SSR, December 29, 1961. Recovered from https://pravo.by/ImgPravo/pdf/UPK_BSSR_1 960.pdf

Law No. 3275, the Code of Criminal Procedure of the RSFSR Russian. Soviet Federative Socialist Republic (RSFSR), October 27, 1960. Recovered from http://www.consultant.ru/document/cons_doc _LAW_3275/

Law No. 4651-VI, Criminal Procedure Code of Ukraine. Bulletin of the Verkhovna Rada of Ukraine, Kyiv, Ukraine, April 13, 2012. Recovered from http://zakon5.rada.gov.ua/laws/show/4651-17
Law of Ukraine № 1001-05, Criminal Procedure Code of Ukraine of December 28, 1960 Date of renovation: 19.11.2012. Recovered from https://zakon.rada.gov.ua/laws/show/100105\#Text (date of application: 16.06.2021). [in Ukrainian].

Lepei, M.V. (2017). Seizure of property in criminal proceedings. Kyiv: Istina. Recovered from

http://elar.naiau.kiev.ua/bitstream/123456789/ 1527/1/lepej_avtoref.pdf

Lithuania (1972). Criminal Procedure Code of the Lithuanian SSR. Lithuania: Mintis. Recovered from https://books.google.com.ua/books/about/\%D $0 \% \mathrm{~A} 3 \% \mathrm{D} 0 \% \mathrm{~B} 3 \% \mathrm{D} 0 \% \mathrm{BE} \% \mathrm{D} 0 \% \mathrm{BB} \% \mathrm{D} 0 \% \mathrm{~B}$ E\%D0\%B2\%D0\%BD\%D0\%BE_\%D0\%BF\% D1\%80\%D0\%BE\%D1\%86\%D0\%B5\%D1\%8 $1 \% \mathrm{D} 1 \% 81 \% \mathrm{D} 1 \% 83 \% \mathrm{D} 0 \% \mathrm{~B} 0 \% \mathrm{D} 0 \% \mathrm{BB} \% \mathrm{D}$ $1 \% 8 \mathrm{C} . \mathrm{html}$ ?id=McI0AQAAIAAJ\&redir_esc $=\mathrm{y}$

Ministry of Internal Affairs of the USSR. (1984). Investigative actions (procedural characteristics, tactical and psychological features). Moscow: Norma.

Muzychenko, O.V. (2016). Implementation of the constitutional principle of inviolability of property rights at the stage of pre-trial investigation. Dnipro: Pravo. Recovered from https://dduvs.in.ua/wp-

content/uploads/files/Structure/science/rada/a uto/11/4.pdf

Rudenko, A.E. (2015). Measures to ensure criminal proceedings, restricting the property rights of the suspect, accused and other persons. Kyiv: Istina. Recovered from http://elar.naiau.kiev.ua/bitstream/123456789/ 1400/1/rudenko_avtoref.pdf

Smokov, S.M., \& Lisnichenko, D.V. (2014). Temporary seizure of property: practice and problems of application. Pivdennoukrainskyi pravnychyi chasopys, 1, 148-152. Recovered from

http://nbuv.gov.ua/UJRN/Pupch_2014_1_48 Tatarov, O. (2013). The application of some provisions of the new CPC of Ukraine needs to be standardized. Mytna sprava, 4(2), 182-187. Recovered from http://nbuv.gov.ua/UJRN/Ms_2013_4\%282\% 29_34

United Nations. (1950). Convention for the Protection of Human Rights and Fundamental Freedoms. Recovered from https://www.echr.coe.int/documents/conventi on_eng.pdf 
United Nations. (1952). Protocol (№ 1) to the Convention for the Protection of Human Rights and Fundamental Freedoms. Recovered from https://rm.coe.int/168006377c

Verkhoglyad-Herasymenko, O.V. (2017). On the issue of seizing the property of third parties in criminal proceedings. Visnyk kryminalnoho sudochynstva, 1, 20-27. Recovered from http://nbuv.gov.ua/UJRN/vkc_2017_1_4
Yskandyrov, V.B. (2010). The historical aspect of the development and formation of the seizure of property as a measure of coercion in Russia. Vestnyk YuUrHU, 8, 35-39. Recovered from https://cyberleninka.ru/article/n/istoricheskiyaspekt-razvitiya-i-stanovleniya-nalozheniyaaresta-na-imuschestvo-kak-meryprinuzhdeniya-v-rossii 